\title{
Capacitance Voltage Characterization of Bifacial Silicon Solar Cell Under Polychromatic Modulated Illumination \\ Gökhan ŞAHİN ${ }^{1}$

\begin{abstract}
The aim of this work is to present a theorical study of a capacitance voltage characterization of a bifacial silicon solar cell under polychromatic modulated illumination. From the excess minority carrier's density in the solar cell, the photocurrent density and the photovoltage are derived. The diffusion capacitance was measured with both as a function of voltage and the junction surface recombination velocity. Electric polarization effects are shown through different $\mathrm{C}-\mathrm{V}$ plots. For all the studied parameters, we exhibited the effect of electric field parameters on the capacitance voltage characterization and the operating point of the cell through the junction recombination velocity.
\end{abstract}

Keywords: Capacitance, electric field, silicon solar cell

\section{Geniş Sekturumlu Aydınlatma altında İki Yüzeyli Silikon Güneş Pilinin Difüzyon Kapasitansı ve Aşırı Azınlık Taşıyıcı Yoğunluğu}

ÖZET: Bu çalışmanın amacı, geniş spektrumlu aydınlatma altında iki yüzeyli silikon güneş pilinin difüzyon kapasitansı ve aşırı azınlık taşıyıcı yoğunluğu teorik çalışmasının sunulmasıdır. Güneş pili aşırı azınlık taşıyıcısından fotoakım ve fotogerilim yoğunluğu türetilmiştir. Difüzyon kapasitansı hem voltajın fonksiyonu ile hem de bağlantı yüzeyi rekombinasyon hızı ile ölçülmüştür. Elektrik polarizasyon etkileri farklı C-V (Difüzyon kapasitansı- Gerilim) grafikleri ile gösterilmiştir. Tüm çalış1lan parametreler için, karakterizasyon voltaj kapasitansının elektrik alan parametreleri üzerindeki etkisi ve kavşak rekombinasyon hızı boyunca hücrenin operasyon noktasının etkisi gösterilmiştir.

Anahtar Kelimeler: Elektrik alan, kapasitans, silikon güneş hücresi

Iğdır Üniversitesi, Mühendislik Fakültesi, Electric Electronic Engineering, Iğdır, Türkiye

Sorumlu yazar/Corresponding Author: Gökhan ŞAHİN, konyakayseri@hotmail.com 


\section{INTRODUCTION}

The efficiency of a solar cell depends among others on its intrinsic parameters. Therefore the knowledge of these parameters and control of associated technological processes highlighted below are essential for any improvement of the conversion efficiency expected from the solar cell. Various characterization techniques have been implemented both in static frequency regime (Grove, 1967; Ghitani et al, 1989; Alain, 1997) and in dynamic i.e. transient regime (Nam et al, 1992; Lemrabott et al, 2008). Then solar cell is either under steady state condition (Dieng et al, 2007; Sahin et al, 2015) or under dynamic state (Sahin, 2016) (i.e. transient decay and frequency). That is why many studies have been made on solar cells to improve the conversion efficiency.
This work is based on the effects of the electric field parameters on the capacitance voltage characterization of a bifacial silicon solar cell; these parameters are respectively the diffusion capacitance the bifacial solar cell is front illuminated by a multispectral light.

The bifacial silicon solar cell is represented with all the related equations, followed by the simulation materials and method.

\section{MATERIAL AND METHOD}

The study is based on a bifacial silicon solar cell under polychromatic modulation illumination presented on figure 1 . In order to study the influence of an external electric field on the behavior of the charge carriers in the base, we polarize by applying a voltage, and work in theory quasi-neutral base (QNB).

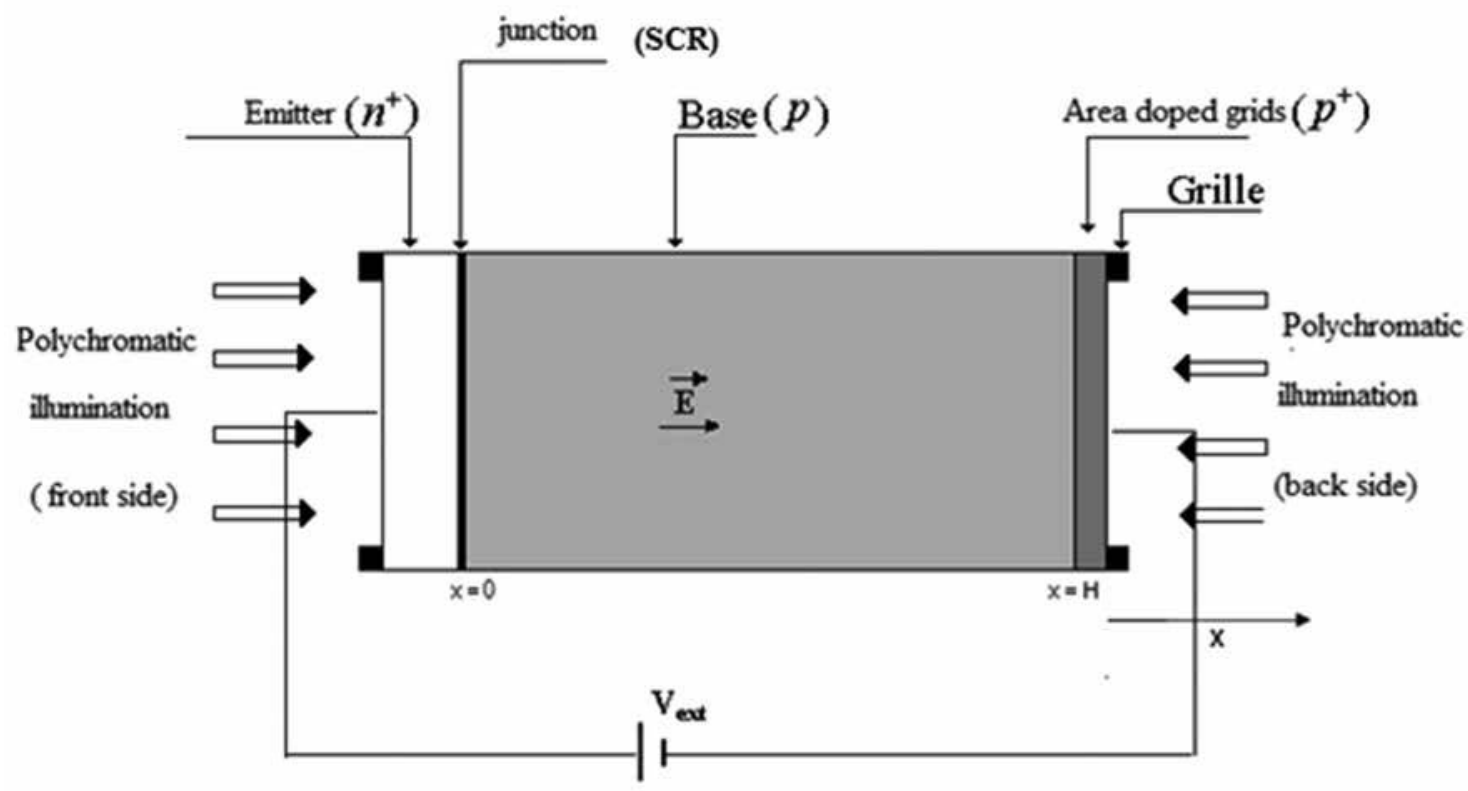

Figure 1. Bifacial solar cell structure to the $\mathrm{n}^{+}-\mathrm{pp}^{+}$type under electric polarization and polychromatic illumination

The solar cell is illuminated by its front side of polychromatic illumination and is under external polarization by applying electric field. The continuity equation for the excess minority carrier's density photogenered in the base under influence of the electric field is:

$$
\frac{\partial^{2} d(x)}{\partial x^{2}}+\frac{m \cdot E}{D} \cdot \frac{\partial d(x)}{\partial x}+\frac{G(x)}{D}-\frac{d(x)}{L^{2}}=0
$$

E the electric field, $\mu$ carriers' mobility. D and L are respectively the diffusion coefficient and the diffusion length of minority carriers. $\delta(\mathrm{x})$ is the minority charge carriers density photogenerated in the base $\mathrm{G}(\mathrm{x})$ is the rate of generation given by (Furlan et al, 1985): 
$G(x)=\sum_{i=1}^{3} a_{i} \cdot e^{-b_{i} \cdot x}$

$a_{i}$ and $b_{i}$ are coefficients from modeling of the generation rate overall radiations in the solar spectrum (Mohammad, 1987).

The expression of the minority carrier's density is given by equation (1) resolution:

$d(x)=e^{b x} \cdot[A \cdot \operatorname{ch}(a \cdot x)+B \cdot \operatorname{sh}(a \cdot x)]+\sum_{i=1}^{3} c_{i} \cdot e^{-b_{i} \cdot x}$

with:

$c_{i}=-\frac{a_{i} \cdot L^{2}}{D \cdot\left[L^{2} \cdot b^{2}{ }_{i}-L_{E} \cdot b_{i}-1\right]}$

and

$L_{E}=\frac{\mathrm{m} E \cdot L^{2}}{D}$
$A$ and $B$ are obtained with the boundary conditions at the emitter - base junction $(\mathrm{x}=0)$ and at the back $\operatorname{surface}(\mathrm{x}=\mathrm{H})$ of the cell (Sane et al, 2013; Ndiaye et al, 2015) expressed as:

-at the junction $(x=0)$ :

$S f=\left.\frac{D_{n}}{d(0)} \cdot \frac{\partial d(x)}{\partial x}\right|_{x=0}$

at the back surface $(x=H)$ :

$S b=-\left.\frac{D_{n}}{d(H)} \cdot \frac{\partial d(x)}{\partial x}\right|_{x=H}$

$\mathrm{Sf}$ and $\mathrm{Sb}$ are respectively the junction and back surface recombination velocity (Sane et al, 2013; Hamidou et al, 2013; Diao et al, 2014).

To understand the electric field effect on extended junction space charge region, we illustrate in Figure 2 junction thickness extension under electric field effect
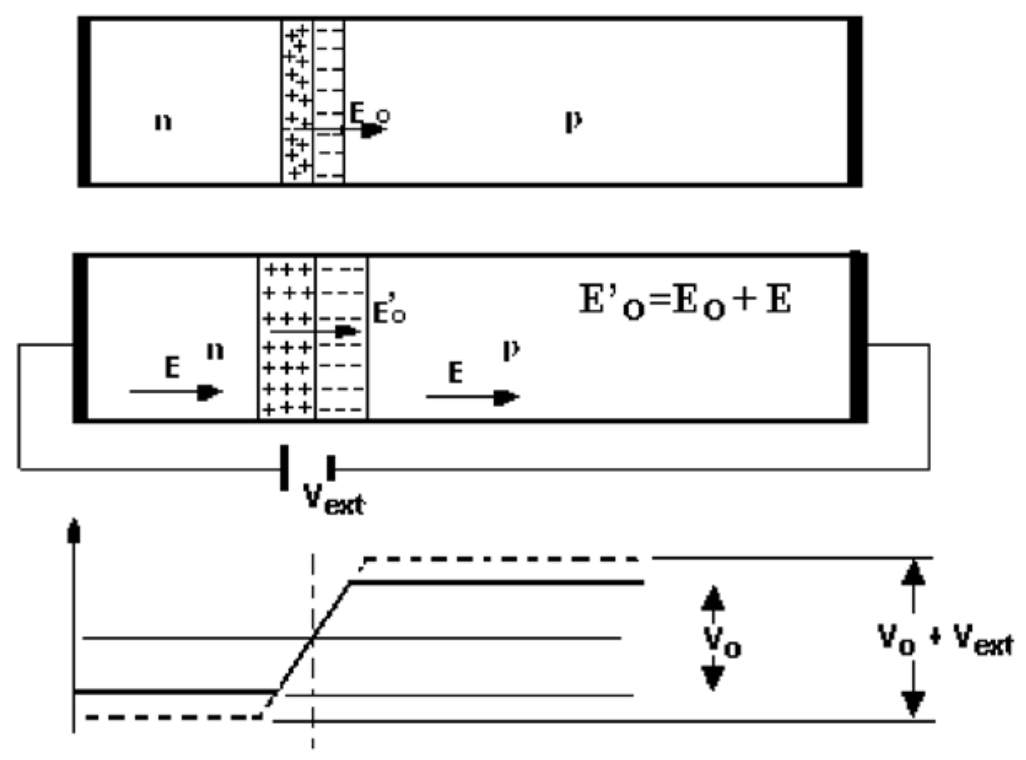

Figure 2. Schematic illustration of the junction thickness extension under electric field effect

Figure 2 shows a reverse polarization of the solar cell. The resulting electric field after this polarization is $\mathrm{E}_{0}{ }^{\prime}=\mathrm{E}_{0}+\mathrm{E} . \mathrm{E}_{0}$ is the electric field in the space charge region without polarization and $\mathrm{E}$ is the electric field from the solar cell external polarization. Vext and $V_{0}$ are respectively voltage from the space charge region in 
the absence of polarization and external circuit voltage. Thus, the minority charge carriers will be returned to the junction by the resulting electric field. These carriers reinforce the diffusion capacitance at the junction and contribute to junction thickness extension

\section{RESULTS AND DISCUSSIONS}

Capacitance study: Diffusing capacitance of the solar cell is considered as the ability of the resulting charge variation during the process of diffusion within the solar cell (Sane et al, 2013; Hamidou et al, 2013; Diao et al, 2014; Barro et al, 2015). It is given by the following equation:

$$
C=\frac{\partial Q}{\partial V}
$$

With:

$$
Q=q \mathrm{~d}(x=0)
$$

By injecting (9) in (8), we have

$C=q \times \frac{\partial \mathrm{d}(x=0)}{\partial V p h}$

If we introduce the excess minority carrier recombination velocity at the junction in equation (8) we obtain following expression of the capacitance:

$$
C=q \times \frac{\partial d(x=0)}{\partial V p h}=q \times \frac{\partial d(x=0)}{\partial S f} \times \frac{1}{\frac{\partial V p h}{\partial S f}}
$$

Or:

$$
V p h=V_{T} \times \ln \left(1+\frac{N_{b}}{n_{i}^{2}} \times d(0)\right)
$$

And:

$$
\frac{\partial V p h}{\partial S f}=V_{T} \times \frac{\frac{N_{b}}{n_{i}^{2}} \times \frac{\partial d(0)}{\partial S f}}{\left(1+\frac{N_{b}}{n_{i}^{2}} \times d(0)\right)}
$$

Therefore:

$$
C=q \times \stackrel{\partial d(x=0)}{\partial S f} \times \frac{1}{\frac{\partial V p h}{\partial S f}}=q \times \frac{\partial d(0)}{\partial S f} \times \frac{1+\frac{N_{b}}{n_{i}{ }^{2}} \times d(0)}{V_{T} \times \frac{N_{b}}{n_{i}{ }^{2}} \times \frac{\partial d(0)}{\partial S f}}=q \times \frac{\frac{n_{i}{ }^{2}}{V_{T}}}{V_{T}} \times\left[1+\frac{N_{b}}{n_{i}{ }^{2}} \times d(0)\right]
$$

Thus,

$$
C=q \times \frac{\frac{n_{i}{ }^{2}}{N_{b}}}{V_{T}} \times\left[1+\frac{N_{b}}{n_{i}{ }^{2}} \times d(0)\right]=\frac{q \times \frac{n_{i}^{2}}{N_{b}}}{V_{T}}+\frac{q \times d(0)}{V_{T}}
$$

Let:

$C o=\frac{q \cdot \frac{n i^{2}}{N b}}{V_{T}}$
Co is the intrinsic capacitance under dark. Replacing $\mathrm{C}_{\mathrm{O}}$ by its expression, equation (17) becomes:

$$
C=C o+\frac{q \cdot d(0)}{V_{T}}
$$


Considering the expression of the photovoltage from equation (10), solar cell capacitance can be expressed as:

$C=C_{0} \cdot\left[1+\frac{N_{b}}{n_{i}{ }^{2}} \cdot \mathrm{d}(0)\right]=C_{0} \cdot \exp \left(\frac{V p h}{V_{T}}\right)$

With equation (18), we obtain

$$
\frac{C}{C_{0}}=\exp \left(\frac{V p h}{V_{T}}\right)
$$

With the logarithmic function, equation (19) becomes:

$$
\ln (C)-\ln \left(C_{0}\right)=\frac{V p h}{V_{T}}
$$

The curve of the logarithm of the capacity versus the voltage is plotted in figure 3 versus photovoltage for different values of the bias electric field

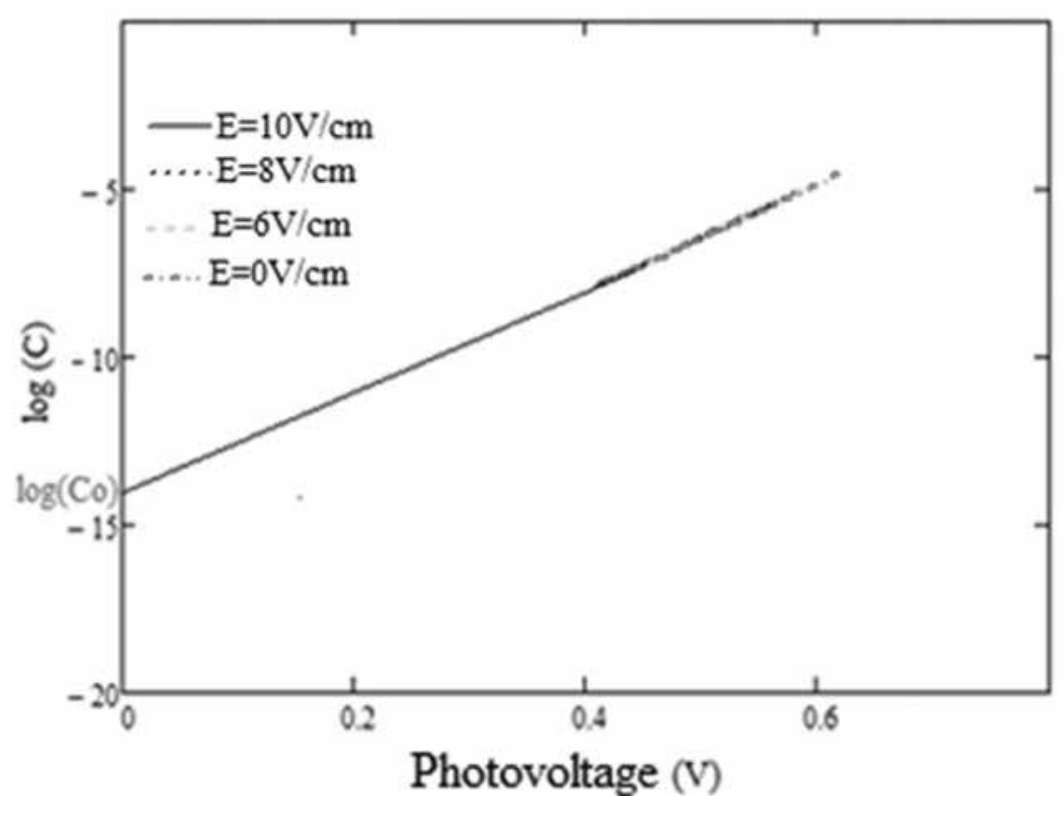

$\left(\mu=10^{3} \mathrm{~cm}^{2} \mathrm{~V}^{-1} \mathrm{~s}^{-1}, \mathrm{~L}=0.02 \mathrm{~cm}, \mathrm{H}=0.03 \mathrm{~cm}, \mathrm{D}=26 \mathrm{~cm}^{2} \cdot \mathrm{s}^{-1}\right)$

Figure 3. $\log (\mathrm{C})$ versus the photovoltage for different values of electric field

This figure shows that the profile of the diffusion capacitance (logarithm scale) versus photovoltage is a straight line of slope $1 / \mathrm{Vt}$ and the intercept of this line with the $y$ axis correspond to $\log \left(\mathrm{C}_{0}\right)$ where $\mathrm{C}_{0}$ is the dark capacitance.

We see that the dark capacitance do not depend on electric field; effectively equation (15) shows that the dark capacitance depend on semiconductor material, its doping and the operating temperature. We see that whatever the capacitance under darkness Co is independent of the electric field polarization. The intercept point obtained with the capacitance axis is the dark capacitance value (Sane et al, 2013; Sahin et al, 2015; Barro et al, 2015). The obtained value with this method is:

$$
\text { Co }=1.8 .10^{-5}\left(F / \mathrm{cm}^{2}\right)
$$

Equation (18) allows us to observe the capacitance evolution versus the photovoltage for different values of electric field. It is represented in Figure 4. 


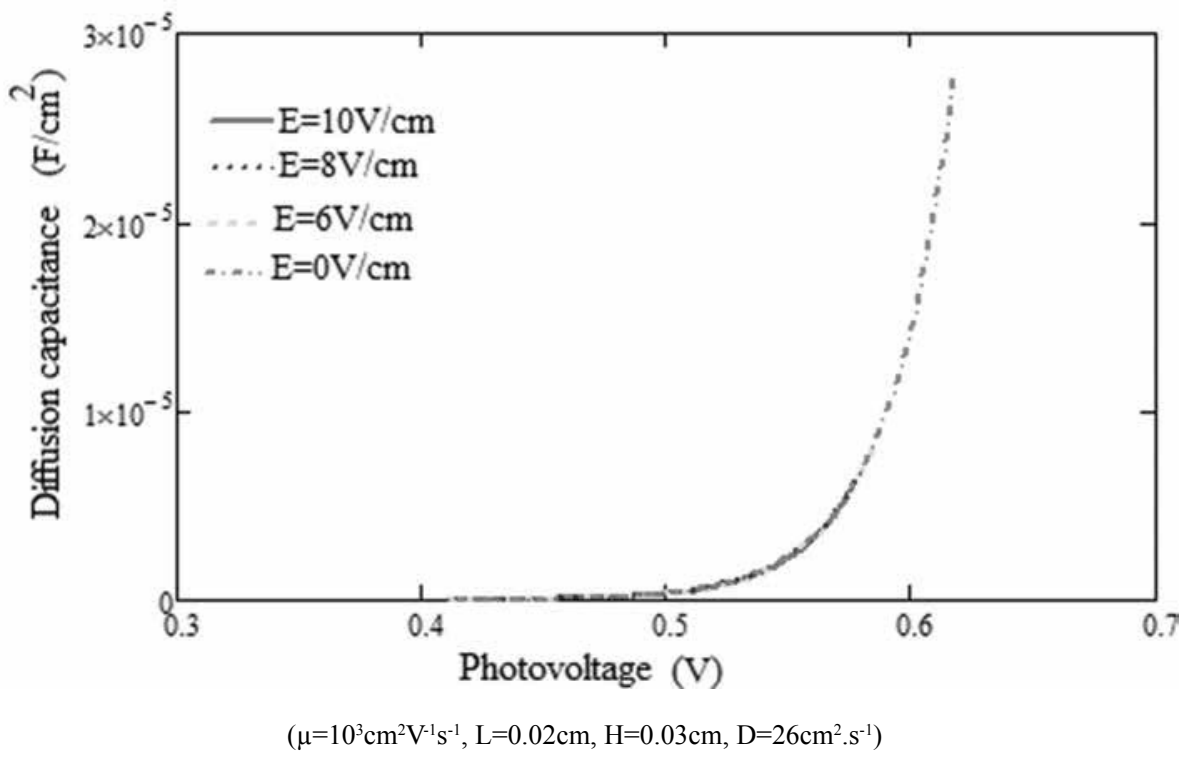

Figure 4. C-V characteristics for different values of electric field

Figure 4 enables us to observe an increase of the capacitance when the photovoltage increases. Thus, for low values of the photovoltage $(\mathrm{V}<0.5$ volts), corresponding to operation of the solar cell in short circuit situation, the capacitance is very low. This is due to the massive crossing of minority charge carriers at the junction. Similarly, for large values of the photovoltage ( $\mathrm{V}>0.5$ volts), corresponding to operation of the solar cell in open circuit situation, the capacitance increases exponentially as a function of the photovoltage which is explained by a significant carrier storage at the junction .
Thereafter, the value of the electric field, we get the same value of the dark capacitance. We also observed an increase in the characteristic when the electric field decreases. Indeed, an increase in the electric field leads a reduction the minority carriers stored in the junction and therefore a decrease in diffusion capacitance.

We represent in Figure 5 the capacitance versus junction recombination velocity for different values electric field:

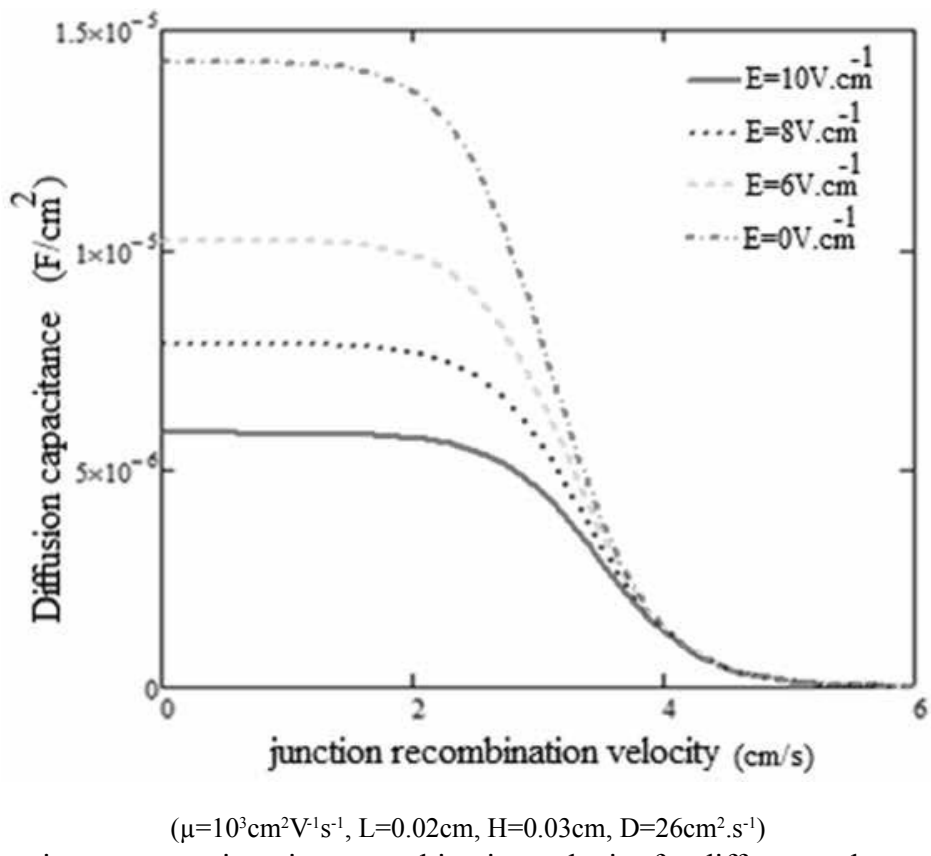

Figure 5. Capacitance versus junction recombination velocity for different values of electric field 
Figure 5 shows that diffusion capacitance decrease with junction recombination velocity; near open circuit, excess minority carriers are stored in the base because they cannot cross the junction leading to an important associated capacitance. Near short circuit, stored charge move to and cross the junction and the associated capacitance decrease.

When the electric field increase, diffusion capacitance increase also because that for higher electric field, carrier paths are incurvated and could not move easily to the junction and cross it. The concentration of carrier in the base in the base is then increased so that the capacitance also increases. The diffusion capacitance is maximum at low values of the junction recombination velocity. Minority charge carriers remain stored at the junction because they do not have enough energy to cross the junction. When the junction recombination velocity increases, the minority charge carriers begin to cross of the junction and the diffusion capacitance. The diffusion capacitance is proportional to the width of the junction by the equation:

$$
C=\frac{S \cdot e}{e}
$$

Where $\mathrm{S}$ is the surface area of the junction and $\mathrm{e}$ its thickness. $\varepsilon$ represent the silicon dielectric constant.

Under these conditions, the junction thickness is accompanied by a decrease in diffusion capacitance. The electric field promotes the flow of minority charge carriers across the junction and decreases the diffusion capacitance.

\section{CONCLUSION}

In this article, the excess minority carrier's density in the base is determinated. The curve of the figures showed a decrease in the density of minority charge carriers with the increase in the electric field. The excess of the phocurrent density and photovoltage deduced from that of minority carrier's density and their profile depending the junction recombination velocity for different values the electric field. We also showed that the electric field increases the photocurrent, decreases photovoltage and diffusion capacitance. This decreased of the solar cell capacitance is accompanied by the junction thickness.
Our computed results have shown that the performance of solar cell is better in the diffusion capacitance range. The capacitance of a crystalline silicon solar cell was investigated; from a one-dimensional model, we pointed out the effects of electric field, illumination level, and junction recombination velocity (related to operating point) on the capacitance. Based on the $\mathrm{C}-\mathrm{V}$ characteristics, a graphical method has been proposed for the determination of both dark capacitance $\mathrm{C}_{0}$ and electric field.

\section{REFERENCES}

Alain R, 1997. Photopiles Solaires, Physique des photopiles, Third Edition Lausanne, 148-155 p.

Barro F I, Sane M, Zouma B, 2015. On the capacitance of crystalline silicon solar cells in steady state. Turk J Phys, 39:122-7. http:// dx.doi. org/10.3906/z-1408-3.

Diao A, Thiam N, Zoungrana M, Ndiaye M, Sahin G and Sissoko G, 2014. Diffusion coefficient in silicon solar cell with applied magnetic field and under frequency: Electric equivalent circuits, World Journal of Condensed Matter Physics, 4, 1-9. http:/www.scirp.org/journal/ wjcmp, http://dx.doi.org/10.4236/wjcmp.

Dieng A, Lemrabott O H, Maiga A S, Diao A and Sissoko G., 2007. Impedance spectroscopy methodapplied to electrical parameters determination onbifacial silicon solar cell under magnetic field. J. of Sci., 7(3): 48-52.

Furlan J and Amon S, 1985. Approximation of the carrier generation rate in illuminated silicon. Solid State Electron, 28, 1241-43.

Grove A S, 1967. Physics and Technology of Semiconductor Devices, First Edition, Wiley, New York. 174 p.

Ghitani H E and Martinuzzi S, 1989. Influence of dislocations on electrical properties of large grained polycrystalline silicon cells, J. App. Phys. 66: 1717-1726.

Hamidou A, Diao A, Séré A D, Moissi A, Thiame M, Barro F I, Sissoko G. Capacitance determination of a Vertical Parallel Junction Solar Cell under Multispectral Illumination in steady state, (IJITEE) Volume-2, Issue-3.

Lemrabott Z N, Bako A, Wereme A and Sissoko G, 2012. Determination of the Recombination and Electrical Parameters of Vertical Multijunction Silicon Solar Cell, Res.J. Appl. Sci. Engineering Technol. Maxwell scientific Organization, 3: 602-611.

Mohammad S N, 1987. An alternative method for the performance analysis of silicon solar cells. J. Appl. Phys. 61(2), 767-77.

Nam L Q, Rodot M, Nijs J, Ghannam M and Coppye J, 1992. Réponse spectrale de photopiles de haut rendement au silicium multicristallin. J. Phys. III France 2, 1305-1316.

Ndiaye E H, Sahin G, Moustapha D, Amary T, Hawa L D, Mor N, Grégoire S, 2015. Study of the Intrinsic Recombination Velocity at the Junction of Silicon Solar under Frequency Modulation and Irradiation, Journal of Applied Mathematics and Physics, 3, 1522-1535.

Sahin G, Moustapha D, Mohamed A O E M, Moussa I N, Amary T, Grégoire S, 2015. Capacitance of Vertical Parallel Junction Silicon Solar Cell under Monochromatic Modulated Illumination, Journal of Applied Mathematics and Physics, 3, 1536-1543.

Sahin G, 2016. Effect of wavelength on the electrical parameters of a vertical parallel junction silicon solar cell illuminated by its rear side in frequency domain, Results in Physics 6, 107-111.

Sane M, Sahin G, Barro F I, Maiga A S, 2014. Incidence angle and spectral effects on vertical junction silicon solar cell capacitance. Turk J Phys, 38:221-7. http://dx.doi.org/10.3906/fiz-1311-9. 
